\title{
Profile of Sports Section and Sports Journalism Practice in Malaysian National Newspaper: Focus on Malay Language Print Media
}

\author{
Sarimah Ismail ${ }^{1, *}$, Hamedi Mohd Adnan² \\ ${ }^{1}$ Faculty of Sports Science and Recreation, MARA University of Technology (UiTM), Malaysia \\ ${ }^{2}$ Department of Media Studies, Faculty of Arts and Social Sciences, University of Malaya, Malaysia
}

Copyright $@ 2016$ by authors, all rights reserved. Authors agree that this article remains permanently open access under the terms of the Creative Commons Attribution License 4.0 International License

\begin{abstract}
Sports and society have a close relationship because they have elements of popular entertainment and leisure. Media is capable of translating popular sports information through the content of sports section or sports pages. Most of newspapers in Malaysia have its own sport sections. Newspaper industry views sport pages as a strategy and value added in the newspaper setting for improving readership and circulation of their publications. Thus, the study shows the practice of sports journalism is very important to give strength to the newspaper sports section in Malaysia. This study focuses on sports journalism of the Malay language newspaper in Malaysia with a focus on the profile of the sports section, the perception of sports editor toward sports section and, sports journalism practices, as well as factor and the importance of the publication of the newspaper sports section. Content analysis method was used to study the newspaper sports section from the two leading media organizations, namely Utusan Malaysia and Berita Harian. The media economic theory was used as the framework of study. The results show the prevailing imbalance of information published in the newspaper sports column. The news of international sports and overseas athletes are given more space than local sports news in the Malaysian newspaper sports section. Advertisements are also found to have considerable influence on the newspaper sports section. The element of contiguity or proximity (events that occur close to the reader) is not a priority element in sports news. The study also found that in order to ensure the survival of newspapers through newspaper advertising revenues, the media would give priority to advertising space. The results reveal that sports section need to sacrifice space to advertisements, and this creates constraints on the sports news and information for publication. Qualitative findings showed that sports editors and journalists in Malaysia do not have an ethical sports journalism guidelines or codes of practice as being practiced in the West. Thus, the daily practice of ethics and practice are based on their own judgments and their professionalism as a
\end{abstract}

media reporter. The study found that all newspaper editors believed that a sports section is a must in a newspaper due to its attraction and followers, which is capable of generating advertising revenue and increasing newspaper circulation. This study also shows that placement of news and articles of sport in the sport sections are based on the media economic fundamentals which focus on newspaper market and advertising revenue. Newspapers sport section has also succumbed to the modern theory of journalism as a result of the competition of the sports information through the advent of the new media.

Keywords Profile, Sports Section, Sports Journalism Practice, Readership, Media Economic

\section{Introduction}

The early theory of journalism or media is more focussing on the role of media to influence, give information and entertainment to the society. However, the development of the world to the industrial and the commercial profit has led to theories of early releases has been replaced by the theory of media economic, a more centric values of economic and commercial, particularly in the field of sports journalism.

Media economic theory is a theory of moden journalism, which was introduced by the economic experts who see the media as an instrument or tool for generating profit for media organization beside playing the main role of media as a means of disseminating information. The relationship between market (marketplace consideration) and media content was very significant in the sport. According to Nancy Cooney, executive editor Philadelphia Inquirer, sports, newspaper sports section has an ability to sell newspaper. She gave this statement when the Philadelphia Philies won the World Championships and the Philadelphia Inquirer newspaper circulation has increased by 20,000 copies 
(Giobbe, 1996). The increase was due to the newspaper's sports column. Therefoe sports section of newspaper is said to be able to increase dynamic readers and advertisers.

As we know, sports, media and the community have a close relationship. Sports require media for dissemination of information and publicity while sport provides information to the media. The theory of Maslow states entertainment is one of the needs in human life. Media and sport have the ability to meet this basic needs. The entertainment value of sports displayed to the public through the media. Beside entertainment value, the theory of media economic has been used to describe the ability of newspaper sports section to acts as the market for new goods and services (through advertising of goods and services) to increase economic revenue of newspaper organization. For example, a newspaper sports section is capable of acting as a sale center of sporting goods.

Allocation of advertising space in sport section, will allow advertisers to have sport section as a market to sell their products. According to the Women Sports Foundation, since 1991, a total of US $\$ 21$ million has been spent by the women to buy shoes and sportswear (Lopiana, 1996) and information relating to sports equipment is obtained from newspaper sports section. For example, information of the type and brand clothes of tennis players in the world are gathered from newspaper sports section and this has affected the purchasing patterns of women against any kind of sports items that they wanted to wear. Generally, media ecomic theory focuses on the market economy and journalism as a commodity that can be sold. Thus, in the development of modern-day journalism industry is to ensure the continuity of the media organizations in the public market.

According to Kinkema (1998) and Rowe (1999) the audience and readers of the sports media are constructing with images and sports information according to the requirements of the needs of media ownership. The definition of the readers and viewers of sports media content is also based on content displayed by this group. Kinkema and Rowe argued that the media ownership have a role in determining the content of the media. However the different situation may arise in the media industry in Malaysia. Therefore, this study looks at the profile of sports section and sports journalism practice in Malaysian national newspaper.

\section{Literature Review}

Since three decades ago, all major daily newspapers making sport stories as a regular newspaper column (Mustakim, 2010). Why is the sports section become a regular newspaper column? According to Baron (2004), a sports column, content and consistent media coverage of sports is able to provide sports development profile and major athletes, creating a ' role model, increasing the amount of readers and viewers, create positive interest toward sport and provide opportunities for more sponsorship in sports. These aspects encouraged newspaper editors in the West to provide more sports space with more pages to the readers.

The theory of media economic has been used to describe the ability of newspaper sports section to acts as the market for new goods and services (through advertising of goods and services) to increase economic revenue of newspaper organization. For example, a newspaper sports section is capable of acting as a sale center of sporting goods.

Thorn \& Pfeil (1987) in their study found that the power of the press is based on three key concepts; the press is an institution of social / political community; the press also is a form of business; and the press is the relationship between the organization and the people in organization (internal staff). All three of these concepts often have conflicting in demands (conflicting demands) for example, a needs towards profitability led to a conflict of demand. In American and capitalist industries, media organizations are expanding based on this factor and will avoid publishing conflict in order to make profit. The race towards profit, make some other publishers are quietly making a profit through the use of sensational newspaper's contents while others sacrifice the good newspaper contents to advertising in order making a profit.

Members of the modern economy practices such as John Walter, managing editor, The Atlanta Journal and Philip Mayer from the University of North Corolina, explained that the economy is a natural push factor in publications of newspaper. Thus, newspaper reader is a customer, news is a production of product and distribution (circulation) is a newspaper market place (McManus, 1994). Members of the classical economists (classical economist) such as Smith (1980) stated that media as an invisible hand which make people, businesses and individuals are forced to adjust the media with the laws of economics.

The modern economy practitioners, clearly shows that the operation of newspaper industry is on the road of making profit, except for the press that gets subsidies from other institutions such as the government, political parties, business or organization. In democratic society, commercial paper has two responsibilities which that led towards conflict in the newspaper organization itself. The first is the role of the press as a disseminator of information to the public but at the same time need to attract readers and advertiser as much as possible to achieve a strong financial position.

Thorn \& Pfeil (1987) explained that a newspaper organization will not succeed in fulfill both demands and normally will only successful in one activity, which is profit . The concentration towards profitable in the newspaper business have resulted in bias or distortion in the contents of newspaper.

According to journalists who fight for professionalism in journalism (Begdikian, 1990, Bernstein, 1992), the market has been contaminated newsroom with the desecration and blasphemy in the news. This situation led to Bernstein (1992) blamed the orientation of modern journalism for creating " idiot culture" in the world of news journalism when accuracy is no longer a major issue for newspapers or television content, but the ability to increase market news is becoming 
the main focus .

According to Bagdikian (1990), the market in journalism has gathered readers and viewers not to provide information but to sell them to advertisers. Another media critic, Herbert Gans (1985) said media news content has been caught in the midst of war between resources and users and Altschull (1984) stated that the ability to pay to the media contents will be advantageous and in this context he refers to the advertiser. Mayer (1987) who is the main supporter to the media economic and against on classic journalism (which is concentrating only on the information must be based on news value alone) stressed that market in journalism gives readers and viewers more diverse selection of information. The information contained in the media is based on the mechanisms of democracy with the choice of buyers and sellers producing products (based on the buyer's choice). This allows news and information published by the press and other media will becoming more attractive and meets the requirements of the buyer. Diversity in the content of newspaper can increase competition in the media industry and expand the market for newspapers (Mayer, 1987)

Michael Fencher, executive editor of The Seattle Times, who heads the media group said that the editor of the modern economy which is successful must be a "marketing expert" (marketing specialist) in the world of journalism (McManus, 1994). According to him, the editor must be able to integrate the business with parts of the news (example providing advertising space for sports gymnasium, organizing educational seminars for education section). He further explained that, the world of journalism in the 1990s had a fierce rivalry, and the economy will enable media continue to compete in this industry. For economists of modern media, classic journalism is no longer able to compete in an increasingly challenging global economy. Thus, journalistic media based economy must be driven in the today's media industry (McManus, 1994).

In the theory of markets and journalism, marketplace is media organization that produces media products for the revenue of journalism market. The market place is a place where people buy and sell goods and services. When implemented properly and effectively, the market has the advantage of providing the public with goods and services that will be cherished and delight both the buyer and the seller (Main \& Baird, 1981).

Stepp (2007) states that newspaper business that based on economy has made newspaper is reshaping the contents of newspaper towards more market (economic) value by giving readers more power (influence) and role in the content of newspaper. The changing in the traditional newspaper lead are also can be seen in most of major newspapers in the world. Newspaper headlines focused on the issues of family, hobbies, sports and news stories are getting shorter, more visuals, more plans and "personality journalism" and the contents of newspapers are also made in line with the television's content (display many visual images). In fact, this change has led some researchers such as
Bernstein (1992) and Bagdikian (1990) criticized the media economic of media that allows the reader to determine the content of the newspaper. According to them, this intervention will lead to bias or slant in the content of the newspaper.

Stepp (2007) explains that current modern journalism shows that sport is under the entertainment category and is the favored by readers. However, the content of the newspaper sports page or section is controlled by the reader, the market and the owner of the newspaper as explain by media economic theory. In this situation, the journalistic professionalism is not a major factor towards the content of sports section and this will lead to bias or distortion in newspaper sport section.

The question is, does the same situation happen in the newspaper industry in Malaysia? The world's leading sports championships often produced information widely in the local daily newspaper. The popularity and the image of sports Championship were formed as a result from the focus of the media towards the tournament /Championship. In this aspect, does the editor of the local newspaper sports section have a special Justification in making a decision on the content of the newspaper's sports section respectively? If Yes, what is the justification used in determining the content of free space in each newspaper?

The aspects of ownership has also been identified to see its influence towards the practice of sports journalism in Malaysian media. Studies done by several other researchers, also revealed that the society looked at the media as a dissemination of information and bias existed in the information (ASNE, 1999).

Studies done by several other researchers, also shows the society looked at the media as bias in dissemination of information (ASNE, 1999; Petterson and Donsbach, 1996; Johnstone, Slawski and Bowman, 1976). The Media is said to be favoured at certain parties in its information delivery. It can be concluded that information obtained from bias sources and variations to meet the need of readers cause the contents of the newspaper to be biased. The tendency of the media focusing on foreign sports news causes the contents of the newspaper sports columns to be unbalance. In these aspect, do Malaysian national media is also follows the same rhythm of market needs and influenced by the needs of readers? This question will be discussed in the finding of this study.

Media "bias" can also be referred to describe the attitude of media editors and reporters in presenting sport information or sports news in their media. It includes in the selection of an event (events) and how news of the event has been reported. This is happen because, anything published by the media is under the influence and control of those who work in a newsroom as editor, sub-editors and reporters. Research on the practice of Journalism will allow researchers to see whether the influence and control of the media people affect the content sports section in Malaysia national newspaper. 
Therefore, the use of the word biased reporting is something that effect toward the practice of journalism and journalism ethic. The direction and degree of media bias in most of the countries are still in dispute even if it causes the deficiencies in terms of practical and theoretical in the content of the news media. The newspaper in Malaysia is likely to use a similar approach in determining the content of the sports section. Detailed study allowed researchers to analyze the content of the Malaysian national newspaper.

Collins (2006) in the Journal of Medicine and Social Science explains the impact of media on the audience or readers is complex. According to him, the bias in media reporting or the contents will affect the readers or viewers. The media impact is divided into four, which are giving information, agenda setting, framing and influence or persuade readers.

Baron (2004) in the research entitled "Persistent Media Bias" states media organizations will be able to control media content through the its silence control or by giving proper consideration before any information has been published to the community. He explained that the control of news and tolerance towards bias will enable the media organization to improve profitability. He also said that the low quality of news will make the price of the publication is getting low. In addition, he stated that bias will be existed more, if there is a monopoly on the ownership of media organizations. This allows the individual to fully control on media content and cause a tendency to biased results.

The relationship between sports and media is a relationship filled with an economic sphere as well as ideological. Notwithstanding the non-commercial spots (sports) remain without media, but commercial sports will always looking for sports fan and media coverage. Media such as printed and electronic media, also depends on sports to increase newspaper circulation and television viewers.

The beginning of the 21 st century saw the dominance of eight global media companies in the world dominated the print media and electronic media. Between the media conglomerate, News Corporation who controls Fox Television in 1997 and managed to get the air right of the NFL 2005 for a fee of USD 17.6 billion, while America Online (AOL) by Time Warner (media organization in the world) who dominated the combined CNN/Sports Illustrated. The dominance of print and electronic media on a big scale is making economic benefits through sports events. This giant media see sports as a market economy of media organization. Therefore media are looking at sports as an advantage in making profit and it is necessary to have a marriage between sports and media.

Straubhaar and La Rose (2004) outline among the functions of the media is as change values and socialization. According to them, this is done through the transmission of ideas from one generation to another generation. Sports section in printed media or electronic media is representing society around them. Therefore sports and society are interconnected and sports are said to reflect the social cultural community. For example, sumo reflects Japanese society whilst Tomoi sports representing society of Thailand.

However, media concentration towards the deeper economic market, the function of sports as a cultural and social community is left behind. Stepp (1991) found that the change from traditional journalism in the era of modern journalism, media organization in the world are more focusing on reader-based market and ownership has brought a great difference in the content of the newspaper especially in the sports section. Based on the previous literature review, it is interesting to see whether the local national newspaper in Malaysia is also having the same practices as western media towards their sports section.

To understand the content of media, the form of the sports section in printed media, the type of media, who is responsible for the content of media and other questions that related to media, we will face a variety of different answers to the questions which describes a variety of assumptions on how communities and individuals function in a society. In this aspect, LaRose (2004) in his book "the Media Now. Understanding the Media, Culture and Technology "explains when a media analysis is made, social behavior (social action) or human behaviour theory are formed and they are known as media theories. Relevant theories are helping researchers understand the media around us and explain how our response to the media (LaRose, 2004).

Therefore, in understanding the profile of the sports section in the national newspaper of Malaysia, it is very important to understand the role of the media, the purpose of the contents of a column in the media, the main focus of the media, the layout, the images and illustration that published in the media, as well as factors that led to the existence of the elements. So it's very important to use various theories to explain the issue that has been discussed in this research. As stated by La Rose $(2004,33)$ "Theories help us understand the media around us and how we respond to them". For this research, the theoretical concept of news and newspapers and media theory are used to describe the profile of the sports section as well as factors towards the existence of the sports section in the Malaysian national newspaper namely Utusan Malaysia and Berita Harian.

\section{Objective of Study}

Based on the review of the literature, researchers are focusing on these objectives:

1. To identify the format or profile of the sports section in national daily newspaper.

2. To determine the importance of newspapers to publish sports stories.

3. To identify the criteria used by the newspaper in determining the content of the newspaper sports section.

4. To examine the sports journalism practice among the sport journalist in Malaysian national media. 


\section{Methodology}

Utusan Malaysia (UM) and Berita Harian (BH) were chosen as the sample for this study. The selection was made based on the characteristics and the similarities that appeared in both newspapers concerned. Utusan Malaysia and Berita Harian are the major national daily Malay language newspaper in Malaysia. Both are broadsheet in size and the earliest newspaper based in Malaysia. The physical size of UM and BH (smaller size - half of the broadsheet only changed in full at the end of 2012) are similar - broadsheet. The similarities in features enable measurement, comparison and validity (reliability) both newspapers are more measurable and accurate.

Two methods were used to answer the objective of this study.

1. Content analysis sports section in Utusan Malaysia (UM) and Berita Harian (BH) for 12 months. 48 copies of the UM press and 48 script BH (July 2011-July 2012) used as a review. Instrument form which consists of 56 items was used for content analysis.

2. Qualitative method - face to face interview with the editors of mass media and editorial departments of the sports section (sports editor, Assistant sports editor, sports reporter). 4 editorial staff from $U M 4$ editorial staffs of $B H$ was selected as respondents.

Interview questions were designed to obtain desired information. Both methods are used to strengthen the results.

\section{Finding}

\section{Profile of Sport Section}

Data analysis shows that the profile of the sport section in both newspapers based on the modern sports journalism, which focusing towards economy and the media market. There was no significant difference in terms of the content of the newspaper sports columns of $U M$ or $B H$.

Both papers focus on a wide range of sports information that can expand to readers and advertisers as well. The news value of "proximity" is not given into consideration in determining the content of the sports section. The press has more focused to sports information that may create the interest of readers and give commercial values to them.

Sports news writing is the most prominent information in the sports section (32.6\%) followed by other sports information (diary sports, statistics, tables) $29.9 \%$, advertising by $28.8 \%$ and sports feature writing show the lowest percentage at only by $8.7 \%$. Both newspaper's organizations, give more space for current news of sports. Other preferences information is seasonally according to the current state of sports in Malaysia and internationally. Both newspapers are focusing toward sport stories that have the ability of creating competition with other newspapers.

Based on the entire pages of newspapers, $U M$ allocated $13.92 \%$ and $B H 14.46 \%$ for the sport pages. The $U M$ gives higher focused on international sports stories $(52.3 \%)$ than local sports $(47.7 \%)$. This is contrasted with $B H$ which is giving more focus for local sports stories $(51.1 \%)$ than international sports stories $(48.9 \%)$.

There are 19 types of sports information that covered by a newspaper which including sports issues (regarding training, salaries, drug use and so on) in the newspapers surveyed. The highest five of most coverage sports, are football, sports issues, badminton and tennis. Football is the dominant sport, which recorded the highest coverage, which is 13.9 per cent, followed by badminton and sports issues by 8.9 percent and tennis by 8.1 per cent.

The advertisement is also dominated sports section of the $U M$ and $B H$. This situation exists because advertising is an important element for increasing the revenue of the newspaper company. The percentage of ads in $U M$ are $28.3 \%$ and $\mathrm{BH}$ is $29.4 \%$. This situation clearly supports the opinion of Real (1998) which stated the primary push factor in the sports media are to make profits, sponsorship, expand the market for goods and competition. Sports section has been commercialized by a media organization with the purpose of generating income. Results showed that both newspapers willing to publish any kind of ads in the sports section. The finding shows that ads which is not related to sport is higher (67.4\%) than sports-related ads (32.6\%).

Interesting to note, the finding from this study also reveals the bias of coverage in term of gender. The data show that both newspapers gave more coverage for men athletes, which is $49.2 \%$ and women athletes only $33.7 \%$. The coverage for the sports that involves both genders are only $17.1 \%$. Although the sports involved in both genders, men are still the main focus and the dominant in the local newspaper.

This finding is in line with the opinion of Boutiller and San Giovanni 1983; Daddario 1994; Matheson and Flatten, 1996, that stated media see women athletes don't have the news value than men. This supports the opinion of Michael Fancher, executive editor of The Seattle Times that competition in the media in the 1990s resulted in the media are not able to continue traditional journalism in total and need to shift to modern journalism by continuing competition and finding ways to increase the daily income (Schor 1992; Coen 1992).

To increase sales, readers and advertisers, both newspapers $(U M$ and $B H)$ are willing to give more space and coverage for foreign sports stories and international athletes and teams ( $U M$ 56.9\% and $51.3 \% \mathrm{BH}$ ). This factor has been deflecting elements of traditional news value (proximity). The media economy in this context successfully shifting away the traditional patterns of information and news.

\section{Sport Journalism Practice In Malaysia}

The significant role played by sports section is the attraction to some newspaper readers. Almost all major newspapers in Malaysia (whether large-sized newspaper or tabloid) provide sports section in their newspapers. In the opinion of Respondents $(U M)$, the sports section has been able to attract readers around the age of $18-40$ years. 
This is aligned with the view of Four (2004) and Coakley (2005) that explained the main attraction of newspaper contents in addition to the aspects of politics, economy and education is sports. According to both researchers, sports titles are searchable by newspaper readers. Good to note, favored sports are able to provide information in the form of entertainment to the readers compared to other topics in the newspapers.

According to all respondents ( $U M$ and $B H$ ), their newspaper also displays, sports stories that can sell newspapers to readers. The readers are free to choose sports information that published in their sports section. However, sports editor had to choose sports stories that can create interest to readers, selling newspapers and are able to attract advertisers as required by their organizations. Results of interviews reveal, editor of sports had to face constraints in the sports section. Every day, ads space will get placed in newspaper section before news stories, and this is the policy of both newspapers. In this situation, sports page gives way to layout of ad space in advance prior to the layout of the sports stories is the daily practice of $U M$ and $B H$.

\section{Sport Journalism Ethic}

All respondents from both newspapers agreed that journalism ethics are the most important element in their journalism practice. They must have knowledge of games or sports, honesty in reporting, understand the emotions of athletes and sports fan enthusiasts, and proper ethics in reporting.

This does not mean that reporters need to be a member of the sports organization or association. The Respondents also agreed that they had not been exposed to the practice of violating ethics such as bribery when carrying out their duties. They are always being professional in order to obtain the best information for news coverage. The current practice of getting a free item or gifts is not considered as a deflection in the sports journalism practices. In the opinion of the all respondents, these types of gifts are more towards the appreciation of organizer of an event towards the journalist that come to do coverage of the event. Since, there is no policy that again this practice, all the respondents feel that, it is not wrong for them to accept this kind of gifts.

It is a common practice for every organizer of sports events in Malaysia to provide gifts for Malaysian media who do coverage for their event. This is in line with the Canada Ethics Sport Policy compiled by Gary Sosniecki, editor of sports, Southern Illinoisan in 1979 (Garisson, 1985), which saying "granting of a souvenir, and the use of journalist pas for coverage, is not considered a breach of ethics for sports journalism".

\section{Significant}

There are three major significance of this study:

1. The finding from this study can be used to provide guidance to enhance the standard of sports journalism practice in Malaysia.

2. These findings could add media practitioners knowledge of the weakness issues in the sports section and journalism practices.

3. The $U M$ newspaper has used the finding from this study to improve the newspaper sports section. As the result, the newspaper has appointed columnist to write articles/analysis related to current sports issues for the newspaper.

\section{Conclusions}

Media organization policy, environment (advertisers) and journalism ethics are very important in the shaping sports journalism practice in Malaysia. Sport Editor should consider this factor as there are distinctive influences that affect the content of sport section and sport journalism practice in Malaysia. Newspapers have to give more coverage for local sports events in an effort to build interest and trust among local sports fan. The allocation of ads needs to be reviewed so more space can be allocated for sports stories and sports news.

Malaysian Press perceived foreign sports news has more news value than local sport news. The perception of Malaysian sports journalists is in line with Stepp (1991) which states that the newspapers in the world, whether the newspaper industry is small or large have been reshaping news by giving the reader controlling the content of newspapers. Both newspaper organizations ( $U M$ and $B H$ ) believed that Malaysian sports fan is more interested toward foreign sports especially football. This perception actually drive the contents of sports section in the Malaysian national newspaper indirectly has been controlled by readers (consumer). The newspaper industry, in the situation of generating income and facing with the needs to increase the income of its organization have to follow media economic practice. The practice of media economy in the media industry, which focusing toward market value and demand of consumer will affect the contents of newspaper sports section and need to be reduced to ensure the quality of the Malaysian newspaper sports section.

\section{Acknowledgements}

This research had been funded by Universiti Teknologi MARA (UiTM) and I would like to thank the management of Universiti Teknologi Mara and the Faculty of Sports Science and Recreation, UiTM for the funding and support of this study.

\section{REFERENCES}

[1] Altschull, J. H. (1984). Agent of power: The role of the news media in human affairs. White Plains, N.Y: Longman. 
[2] American Society of Newspaper Editor (ASNE), www.asne.org.

[3] Baran, S. J. (2004). Introduction to Mass Communication: Media Literacy and Culture (Edisi ke-2). Boston: McGraw Hill.

[4] Baron, D. P. (2006). Persistent Media Bias, Journal of Economic, 90(1):1-36.

[5] Baron, David P. (2005). Competing for the public through the news media. Journal of Economics and Management Strategy. 12 (spring).

[6] Bauer, M \& Gaskal, G. (2000). Qualitative researching with text, image and sound. London: Sage Publications.

[7] Begdikian, Ben H. (1990). The media monopoly ( $3^{\text {rd }}$ edition). Boston: Beacon Press.

[8] Bernstein, C. (1992). Feeding an "idiot" culture, San Jose Mercury News. 21 June 1992.

[9] Coakley J (2005). Sport in Society. Issues \& Controversies ( $7^{\text {th }}$ Edition), Boston: McGraw Hill.

[10] Collin, P. (2006) 'United we fall', British Journalism Review, 14(4): 49-54.

[11] Curran, J., \& Seaton, J. (1991). Power without responsibility. London: Routledge.

[12] Coen, R.J. (1992). Robert J. Coen Data. The Economics of Advertising. New York: McCann-Erickson World Wide Publisher.

[13] Collin, P., Abelson, J., Paymen, H., and Lavis, J. (2006). Are we expecting too much from print media? An analysis of newspaper coverage of 2002 Canadian Healthcare Reform Debate. Social Science and Medicine. 63 (1) : 89-102.

[14] Gans, H.J. (1985). Are U.S journalists dangerously liberal? Columbia Journalism Review, 24(4), 29-33.

[15] Garrison, B. \& Sabljak, M. (1985). Sport Reporting. Ames, Iowa: The Iowa State University Press.

[16] Garrison, B. \& Salwen, M. B. (1989). "Professional orientations of sports journalist - A study of Associated Press Sports Editors.” Newspaper Research Journal, vol.10, No.4, $77-84$.

[17] Gary, S. (1979). Sports Department Ethics Policy. Southern Illinoisan. Illinois.

[18] Giobbe, D. (1996). Bertha Blows Over. Editor \& Publisher. Volume 129, No.20.

[19] Jack, O. (1970). The Rosenbloom-robbie Bowl. Sports Illustrated. 9 November, 1970.

[20] James R. H. and Richard N. A. (1999), 'Gender Equity in Televised Sports: A Comparative Analysis of Men's and Women's NCAA Division 1 Basketball championship Broadcasts, 1991-1995'. Journal of Broadcasting \& Electronic Media. Mac, 111-215.

[21] Jane C., Paula H., Bart G. (1994). A content analysis of sports section of Canada's National Newspaper with respect to gender and professional/amatur status, International Review for the Sociology of Sport, Vol.29, No.2, 123-132. SAGE Publication
[22] Kinkema, K. M., \& Harris, J.C. (1998). Media Sport studies: Key research and emerging issues. In L.A. Wenner (Ed.), Media Sport (pp. 27-54). London: Routledge.

[23] La Rose, R. \& Straubhaar J. D. (2007). Media now: Understanding media culture and technology $\left(5^{\text {th }}\right.$ ed). New York: Wadsworths Publishing.

[24] Lopiana, D. (1996). “ Marketing trends in women's sports and fitness,". Women's Sport Foundation, www.lifetimetv.com/sports/index.html.

[25] Main, R.S., \& Baird, C.W. (1991). Elements of microeconomics ( $2^{\text {nd }}$ edition). St. Paul, MN: West.

[26] Mayer, P. (1987). Ethical journalism. New York: Longman.

[27] McCleneghan, J. S. (1990). Sportswriter Talk About Themselves: An Attitude Study, Journalism and Mass Communication Quarterly, Columbia: Spring 1990. Vol. 67, Iss. $1 ;$ p. 114 .

[28] McManus, J. H. (1992). Serving the public and serving the market: A conflict of interest? Journal of Mass Media Ethics, 7(4), 196-208.

[29] McManus J. (1994). Market-Driven Journalism. Let The Citizen Beware. London: Sage Publication.

[30] Messner, M.A. and D.F. Sabo (eds). (1994). Sex, Violence and Power in Sports: Rethinking Masculinity. Freedom, CA: The Crossing Press.

[31] Meyer, P. (1987) Ethical Journalism. University Press of America, Lanham, MD.

[32] Meyer, W. H. (1988). Transnational media and third world development: The structure and impact of imperialism. Westport, CT: Greenwood Press.

[33] Mustakim Aminuddin (2010). Peranan media dalam sukan. Seminar Sukan anjuran Fakulti Sains Sukan dan Rekreasi, UiTM, Shah Alam.

[34] Petterson, T. E. and Donsbach W. (1996). News decision: Journalists as partisan actors. Political Communication. 13:453-68.

[35] Real, M. R. (1975). Super Bowl: Mythic spectacle. Journal of Communication, 25(1), 31-43.

[36] Real, M.R. (1989). Super media: A cultural studies approach. Newbury, CA: Sage.

[37] Real, M.R. \& Mechikoff, R.A. (1992). “Deep fan: Mythic identification, technology, and advertising in spectator sports.' Sociology of Sport Journal, 9, 323-339.

[38] Real, M.R (1986). Exploring media culture. California: Sage.

[39] Rowe, D. (1992). 'Modes of Sports Writing', in P. Dahlgran and C. Sparks (eds), Journalism and Popular Culture. London: Sage. Rowe, D. (1992). 'Modes of Sports Writing', in P. Dahlgran and C. Sparks (eds), Journalism and Popular Culture. London: Sage.

[40] Rowe, D. (1999). Sport, culture, and the media: The unholy trinity. Buckingham and Philadelphia: Open University Press.

[41] Schor, J.B. (1992). The Overworked American: The Unexpected Decline of Leisure. New York: Basic Books. 
[42] Smith, A. (1980). The Glasgow edition of the works and correspondence of Adam Smith, vol.3, p.49, edited by W.P.D. Wightman and J.C. Bryce, Oxford: Claredon Press.

[43] Stepp, C. S. (2007). The elements of journalism: What news people should know and the public should expect. Three River Press.
[44] Thorn, W. \& Pfeil, M. (1987). Newspaper circulation. UK: Longman.

[45] Wilstein, S. (2002). Associated Press Sports Writing Handbook. New York: McGraw-Hill.

[46] Woodward, S. (1949). Sports Page. New York: Simon and Schuster. 